\title{
Payoffs To Equity Investment Styles On The JSE Securities Exchange: The Case Of South African Equity Market
}

Kathleen Hodnett, PhD, University of the Western Cape, South Africa Heng-Hsing Hsieh, PhD, CFA, University of the Western Cape, South Africa Paul van Rensburg, PhD, University of Cape Town, South Africa

\begin{abstract}
Empirical tests of market efficiency reveal anomalies that cannot be explained by the capital asset pricing model (CAPM) of Sharpe (1964) and Lintner (1965). These anomalies are firm-specific and can be applied to form potential alpha-generating investment styles that capture the characteristics of the anomalies. We estimate and examine the consistency of the payoffs to firmspecific attributes for South African stocks listed on the JSE Securities Exchange (JSE) over the period from 01 January 1997 to 31 December 2007. The firm-specific attributes under examination are extracted from five categories, namely (1) fundamental values relative to share price, (2) solvency and liquidity, (3) fundamental growth, (4) size and return momentum and (5) consensus analyst forecast. Our test results extract significant attributes from all categories with the exception of the solvency and liquidity category. More specifically, we find that firms with higher fundamental values relative to their share prices, firms with higher dividend and earnings growth, firms with lower market capitalization, firms with higher short-term returns and firms with higher earnings forecasts earn relatively higher returns in the subsequent period in a consistent manner.
\end{abstract}

Keywords: Firm-Specific Attributes; Efficient Market Hypothesis; Style Anomalies; Size Effect; Value Effect; Momentum Effect; Style Payoffs

\section{INTRODUCTION}

2 odern portfolio theory postulates that the only relevant risk in pricing assets is systematic market risk. Firm-specific attributes computed from accounting fundamentals and historical stock prices are deemed to be unsystematic, diversifiable in large portfolios and thus irrelevant in pricing assets. Empirical literature, on the other hand, supports the merits of firm-specific attributes in asset pricing and regards them as capital market anomalies. The value effect, size effect and momentum effect are pursued by asset managers to develop distinctive investment styles from firm-specific attributes. In the South African equity market, Van Rensburg (2001) identifies three major style clusters, namely size, value and momentum for stocks traded on the JSE Securities Exchange (JSE). This paper attempts to explore market anomalies on the JSE by examining the influences of firm-specific attributes in differentiating the cross-section of JSE equity returns over the period from 01 January 1997 to 31 December 2007. We first estimate the factor payoffs to firm-specific attributes using the cross-sectional regression of Fama and Macbeth (1973) from five categories, namely (1) fundamental values relative to share price, (2) solvency and liquidity, (3) fundamental growth, (4) size and return momentum and (5) consensus analyst forecast. The payoff to each attribute under examination is calculated monthly over the examination period. The time-series mean payoffs for the attributes are computed over the entire examination period and two subperiods, from 01 January 1997 to 31 December 2001 and from 01 January 2002 to 31 December 2007. We investigate the statistical significance and the signs of the mean payoff to the attributes, with the objective of identifying firm-specific attributes that differentiate the cross-section of JSE equity returns in a consistent manner. 


\section{LITERATURE REVIEW}

\section{Capital Market Anomalies in the U.S. and Developed Economies}

The size effect, where firms with small market capitalizations outperform their counterparts (firms with large market capitalizations), are well documented. This effect was initially tested by Banz (1981) who adopts a methodology similar to Fama and Macbeth (1973). Using firm size (as measured by market capitalization), in addition to beta to explain the cross-section of equity returns, the author finds a negative relationship between average stock returns and firm size, after controlling for risk, of common stocks listed on the New York Stock Exchange (NYSE), over the period from 1927 to 1975. Keim (1983), Reinganum (1983) and Blume and Stambaugh (1983), find that the small-firm effect occurs in the month of January and is thus a small-firm-in-January effect. The size effect is further emphasized by Fama and French (1992), who sort stocks according to both size and beta. Results conclude that high-beta stocks do not produce higher returns than low-beta stocks of the same size.

According to the value effect positive abnormal risk-adjusted returns accrue to portfolios of stocks possessing high ratios of fundamental values relative to their share prices, for example, high dividend-to-price (D/P or dividend yield), high book-to-market (B/M), high cash flow-to-price (C/P), to name a few. Thus, by examining the ratio of a stock's price (market value) relative to its fundamental value (and vice versa), stocks can be classified as either value stocks or growth stocks. For example, firms possessing low B/M, low C/P, low earnings yield and low dividend yield are classified as growth stocks, while those possessing high $\mathrm{B} / \mathrm{M}$, high $\mathrm{C} / \mathrm{P}$, high dividend yield and high earnings yield, are classified as value stocks. Early tests on the value effect by Basu $(1977,1983)$ finds that companies with high earnings-to-price ratio (or low price-to-earnings (P/E) ratio) earn positive abnormal returns on the New York Stock Exchange (NYSE).

Further evidence of a value effect is reported by Litzenberger and Ramaswamy (1979) who document a positive relationship between dividend yield and common stock returns over the period from 1936 to 1977; Bhandari (1988) who documents a positive relationship between leverage and average returns; Statman (1980) and Rosenberg, Reid and Lanstein (1995) report a positive relation between B/M and average returns. Fama and French (1992) combine the following attributes, namely, market beta, size, leverage, book-to-market equity and earnings yield in the cross-section of average returns on the NYSE, American Stock Exchange (AMEX) and the over-the-counter NASDAQ stocks over the period from 1963 to 1990. Stocks are sorted and ranked according to each respective attribute and portfolios formed. Portfolios range from extreme value-oriented to extreme growth-oriented. The results reveal that beta does not explain the cross-section of average returns, the central prediction of the SharpeLintner model. Size and B/M have the strongest relation to average returns, with a stronger role being afforded to $\mathrm{B} / \mathrm{M}$. The explanatory power of the other attributes disappears when size and $\mathrm{B} / \mathrm{M}$ are included in the regression. Fama and French $(1992,1993)$ conclude that size (as measured by market capitalization) and value (as measured by $\mathrm{B} / \mathrm{M})$ actually represent risk factors missing from the CAPM.

Lakonishok, Shleifer and Vishny (1994) examine the value effect using stocks listed on the NYSE and the AMEX over the period 1963 to 1990. Stocks are classified into portfolios based on cash flow-to-price (C/P), earnings-to-price (E/P), book-to-market (B/M), as well as the average historical 5-year growth rate of sales. The results reveal evidence of a value premium where value stocks outperform growth stocks 5 years after formation. Using the same anomalies suggested by Lakonishok, Shleifer and Vishny (1994), Fama and French (1996) find that when using portfolios based on these variables in their three-factor model, no estimates of abnormal performance that are reliably different from zero is evident.

Evidence of the value anomaly is also found in other developed economies. Fama and French (1998) examine data for the period from 1975 to 1995 for stocks listed on NYSE, AMEX, NASDAQ and EAFE (Europe, Australia and Far East). They form portfolios based on B/M, C/P, earnings yield and dividend yield. The results reveal that value stocks earn higher risk-adjusted returns than growth stocks over the examination period. A value premium is reported with $\mathrm{B} / \mathrm{M}$ being the most consistent value proxy. Apart from Italy, high $\mathrm{B} / \mathrm{M}$ stocks outperform low $\mathrm{B} / \mathrm{M}$ stocks in 12 out of 13 markets. Portfolios based on C/P, earnings yield and dividend yield produce similar value premia. Evidence of a value premium in emerging economies is also cited by the authors. 
The final anomaly tested is the momentum effect when past stock returns are used as a firm-specific attribute in the cross-section of equity returns. Evidence of a momentum effect is found by Jegadeesh and Titman $(1993,2001)$, where recent prior winner returns (that is, 1-year or less portfolio return) outperform recent prior loser returns. The authors examine the returns to buying past winners portfolios and selling past loser portfolios on the NYSE and the AMEX for the period from 1965 to 1989 based on 3- to 12-month prior return momentums. Significant abnormal returns are found for the relative strength strategies in the first year following formation. However, these abnormal returns dissipate in the next two years after formation. Evidence also indicates that the relative strength strategy profitability is not due to its systematic risk. These results are confirmed again by Jegadeesh and Titman (2001).

Fama and French (1996), however, conclude that the short-term momentum strategy of Jegadeesh and Titman (1993) cannot be explained by the Fama and French (1993) three-factor model. Carhart (1997), on the other hand, constructs a 4-factor model (extension of Fama and French 3-factor model), by including a factor that captures the possible momentum anomaly in the U.S.

\section{Capital Market Anomalies in South Africa and Other Emerging Economies}

Early South African tests on efficient market anomalies include research conducted by De Villiers, Lowlings, Petit and Affleck-Graves (1986), Bradfield, Barr and Affleck-Graves (1988), Bradfield (1990), Page and Palmer (1991) and Page (1996). Van Rensburg (2001) is one of the first publications to document tests on the identification of style-based effects in South Africa by examining a multitude of candidate style attributes on the JSE. Van Rensburg (2001) examines 23 candidate style attributes using shares listed on the industrial sector of the JSE over the period from 1983 to 1999. Style attributes are categorized into one of the following groups: (1) value, (2) future earnings and growth and (3) irrationality/neglect. By adopting a 'portfolio-based' approach, factor mimicking portfolios are formed with their risk premia assumed to be the spread between the risk premium of the fractile with high attribute and the risk premium on the fractile with low attribute value. Two risk factors identified in this research include a value risk premium and a small-firm risk premium. Anomalies associated with the following nine attributes are identified: (i) earnings yield, (ii) past twelve month returns, (iii) market capitalization, (iv) dividend yield, (v) six month's past returns, (vi) leverage, (vii) cash flow-to-debt, (viii) turnover and (ix) three month's past returns. In a follow-up study, Van Rensburg and Robertson (2003a) adopt the 'characteristic-based' approach of Daniel and Titman (1997) on the JSE over the period from 1990 to 2000. Using cross-sectional regression, share returns are regressed on the values of 24 style attributes. In a univariate test, the time-series factor payoff to each style attribute is estimated. The univariate results provide evidence of a value effect and size effect where the following attributes, namely, price-to-NAV, dividend yield, price-to-earnings, cash flow-to-price, priceto-profit and market capitalization are extracted. Van Rensburg and Robertson (2003b) adopt the methodology of Fama and French (1992) on the JSE. The results reveal that low P/E shares, whilst earning higher returns, also have lower betas. Contrary to international evidence, which find small firms to actually be riskier investments, in this study small capitalization shares are found to earn higher returns, while possessing lower betas. The results are also consistent with the evidence of Fraser and Page (2000) and Van Rensburg and Robertson (2003a) in that the size and value effects are found to operate independently of each other on the JSE.

With regard to emerging market studies, Claessens, Dasgupta and Glen (1998) examine the cross-section of stock returns for 19 emerging economies by examining the effect of several explanatory variables, in addition to beta, on asset returns over the period 1986 to 1993. The results reveal that, in addition to beta, size and trading volume are found to have significant explanatory power in some economies. Earnings-to-price ratio and dividend yield are also found to have explanatory power in fewer economies. Exchange rate risk also has significant explanatory power. The authors conclude that while size, price-to-book ratio and dividend yield have explanatory power, the signs of the coefficients are not consistent with those of developed economies. This is most pronounced for size. Rouwenhorst (1999) examines the sources of return variation in 20 emerging markets over the period 1982 to 1997 . The authors find evidence that emerging market return factors are qualitatively similar to return factors in developed economies. Averaging across all emerging economies, results indicate evidence of a value effect, momentum effect and a size effect. This is consistent with the findings of Fama and French (1998) but inconsistent with the findings of Claessens, Dasgupta and Glen (1998). Serra (2003) examines the role of a set of a priori specified factors in order to determine the commonality in the cross-section of returns across emerging economies 
(including South Africa). The results reveal that the important factors are common across emerging economies and similar to the factors identified in developed economies and that the driving factors in emerging markets are consistent with Fama and French (1998). The six most important attributes in the cross-section of emerging market returns included technical factors (12-week lagged holding period returns), firm characteristics (earnings-price, book-to-market, dividend yield) and liquidity factors (size and price per share). Results do not reveal evidence of a size effect.

\section{DATA AND SAMPLE SELECTION}

The examination period for the research is from 01 January 1997 to 31 December 2007 (a total of 132 months). As of 31 March 2009, 159 shares comprising the FTSE/JSE All Share Index are selected as the sample stocks for this research. The monthly data of the closing stock prices, indexes and firm-specific attributes are downloaded from DataStream International. Firm-specific attributes are divided into five categories, namely, (1) fundamental values relative to share price, (2) solvency and liquidity, (3) fundamental growth, (4) size and return momentum and (5) consensus analyst forecast. Attributes in the fundamental values relative to share price category distinguish value stocks from growth (glamour) stocks. Value stocks have small fundamental values per share relative to their share prices compared to growth stocks. Solvency and liquidity ratios serve as indications for the companies' financial positions. Attributes in the fundamental growth category are historical growth rates in cash, earnings, profit margins, dividends and sales for the companies. Return momentum measures the growth rate in the total return index of the sample shares. The natural logarithm of share price and market capitalization are indications of the current market values of sample shares. Style attributes in the size and return momentum category are pricesensitive attributes. Attributes in the consensus analyst forecast category incorporates analyst forecasts regarding future earnings and dividends. The descriptors of the candidate style attributes as well as their computations are demonstrated in Table 1.

In order to ensure that the sample shares have sufficient liquidity, a turnover ratio is computed by dividing the average number of shares traded daily for a particular month by the total number of outstanding shares on the first day of the month. Shares with equal to or less than a turnover ratio of $0.01 \%$ are excluded for that month to ensure that each sample share is traded at least once in any particular month. In addition, companies that exhibit major corporate restructuring, mergers and acquisitions or share splits are excluded as of the date of the above mentioned corporate event. The database is subject to survivorship bias since only shares listed on the JSE as at 31 March 2009 are considered in the initial sample. This bias is partially addressed through the retention of liquid shares in the research sample, which are generally more established firms that are less likely to be non-survivors. Attributes to be examined are winsorized by setting the maximum and minimum monthly values of each attribute to $99.5^{\text {th }}$ and $0.5^{\text {th }}$ percentiles respectively to remove the extreme outliers in each month. Once the monthly style attributes are free of outliers, the monthly cross-sectional mean of each style attribute is subtracted from the crosssectional distribution of each style attribute. The cross-sectional distribution of each style attribute is subsequently divided by its respective cross-sectional standard deviation. Repeating this procedure monthly enables the monthly distribution of each style variable to be normally distributed over the examination period. Standardizing style attributes allows for comparison to be made amongst style factor payoffs estimated in the cross-sectional regressions. Due to the fact that data are recorded directly from the published financial statement information downloaded from DataStream International with the attributes lagging the corresponding share returns in the regression analysis, the database is not subject to look-ahead bias. 
Table 1: Computation of Firm-Specific Style Attributes

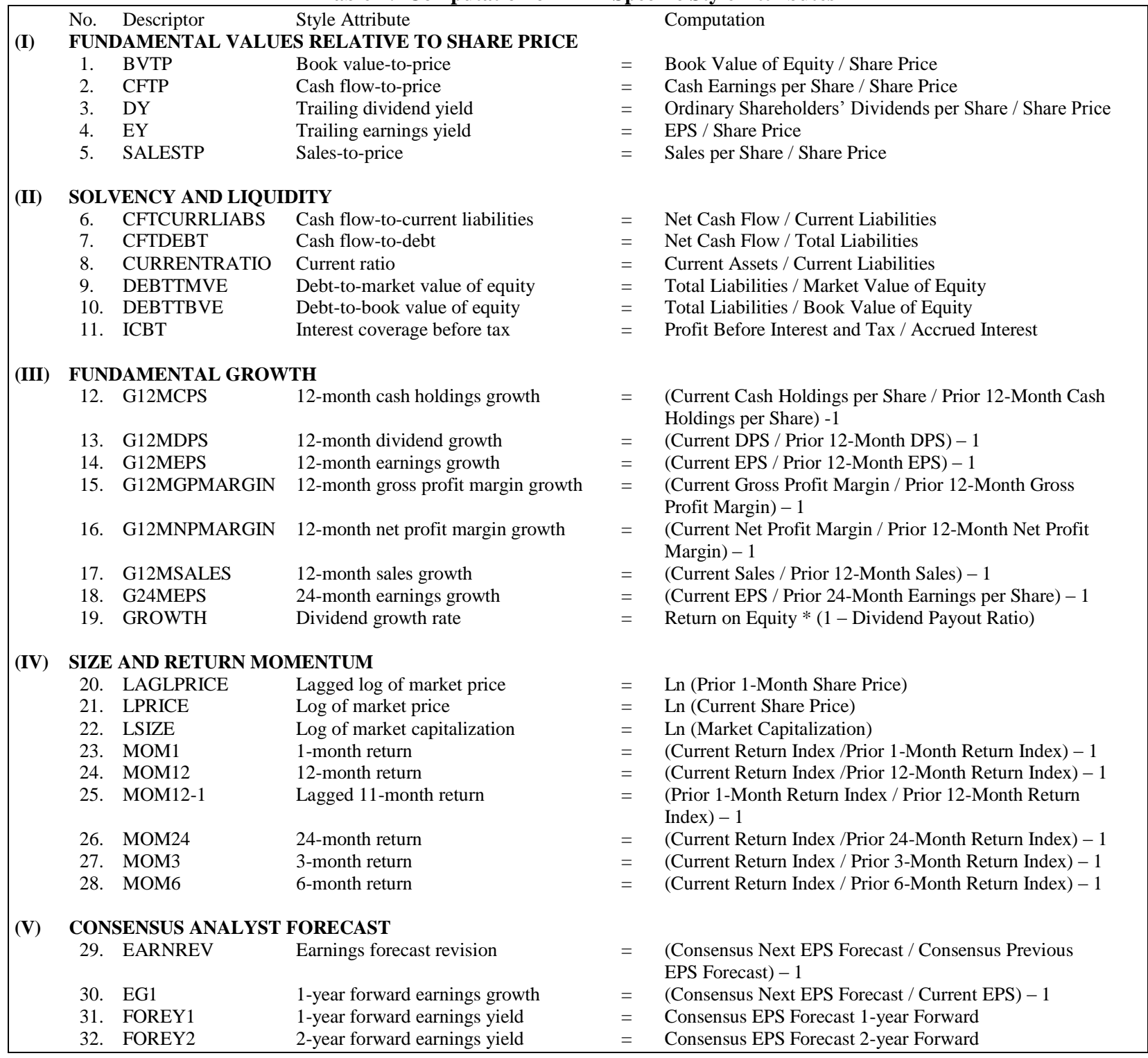

\section{RESEARCH METHODOLOGY}

The factor model of Fama and Macbeth (1973) is employed to estimate the payoff to each attribute monthly as shown in Equation 1.

$$
R_{i, t+1}=a_{t+1}+b_{t+1} \times F_{i, t}+e_{i, t+1}
$$

Where:

$\begin{array}{lll}R_{i, t+1} & = & \text { the realized return on share } i \text { for month } t+1 ; \\ b_{t+1} & = & \text { the estimated cross-sectional payoff to the attribute; and } \\ F_{i, t} & = & \text { the lagged standardized value of the attribute. }\end{array}$


Once the payoffs to the attributes for all the months in the examination period are estimated, the $t$-statistics for the time-series mean payoffs to each attribute for the sub-periods and the entire examination period are computed to determine the statistical significance of the payoffs. In assessing the consistency of the attributes, a binomial sign test, Wilcoxon signed ranks test and Van der Waerden (normal scores) test is employed. The binomial sign test assumes that the sample proportion above and below the median of a binomial distribution should be exactly 50 percent. Consequently, the null hypothesis of the binomial sign test is that the median of the factor payoff to a given style attribute is equal to zero. With regard to the Wilcoxon signed ranks test, the absolute value of the distance of each observation from the mean is calculated and subsequently ranked. Once the observations are ranked, the sum of the ranks of the positive observations is compared to that of the negative observations to determine the direction consistency for the attribute payoffs. The Van der Waerden test, derived from Wilcoxon signed ranks test, is based on smoothed ranks by converting ranks into quantiles of the normal distribution. Since these tests are tests that are based on the median of the distribution, the median of each style factor payoff being tested is set to zero. Thus, if the null hypothesis is rejected for a given style attribute, it is statistically more likely for the style attribute to receive either a consistent positive or negative payoff.

\section{RESULTS}

The characteristics of the attribute payoffs are demonstrated in Appendix A. Both the Student's $t$-test on the attribute mean payoffs and the sign tests on the median of the attribute payoffs are set at 5 percent significance level. Significant $t$-statistics are highlighted in bold. Examining Appendix A.1 through Appendix A.5 reveals that 10 (out of 32) attributes exhibit significant $t$-statistics for their mean payoffs over the first sub-period. Out of these 10 attributes, 3 attributes are from the fundamental values relative to share price category, 6 attributes are from the size and return momentum category, and the remaining attribute is from the consensus analyst forecast category. The explanatory power of the attributes improves drastically in the second sub-period. During this period, 20 attributes significantly explain the cross-sectional equity returns on the JSE. Out of these 20 attributes, 4 attributes are from the fundamental values relative to share price category, 1 attribute is from the solvency and liquidity category, 5 attributes are from the fundamental growth category, 7 attributes are from the size and return momentum category, and 3 attributes are from the consensus analyst forecast category. Although the majority ( 5 out of 8 ) of the style attributes in the fundamental growth category have significant mean factor payoffs over the second sub-period, none of the attributes from this category appears to be significant in the first sub-period.

Over the entire examination period from 01 January 1997 to 31 December 2007, all attributes from the fundamental values relative to share price category, 3 attributes from the fundamental growth category, 1 attribute from the solvency and liquidity category, 7 attributes from the size and return momentum category and all attributes from the consensus analyst forecast category demonstrate their abilities to explain the cross-sectional equity returns. An important observation is that all attributes from the liquidity and solvency category, with the exception of DEBTTBVE, are not able to explain the cross-sectional equity returns over both sub-periods as well as the overall examination period. Examining the results of the median tests on the factor payoffs of the style attributes reveals that most of the significant attributes are associated with significant signs. The detailed discussion of payoffs in each category is discussed below.

\section{Fundamental Values Relative to Share Price}

Examining the $t$-statistics of the mean payoffs to the attributes in Appendix A.1 indicates that all attributes in this category (BVTP, CFTP, DY, EY and SALESTP) have significant mean payoffs over the examination period. In addition, all attributes in this category possess significant positive signs for their payoffs. This means that firms with relatively high fundamental values to their share prices (that is, the value firms) are temporarily undervalued, and the market will correct shortly and reward these firms with higher payoffs. The payoffs to the value firms are well documented in both local and international studies. Overall, the attributes in this category exhibit significant, consistent, positive payoffs over both sub-periods as well as the entire examination period. BVTP and CFTP, amongst other attributes, receive the most positive and consistent payoffs over the examination periods. 


\section{Solvency and Liquidity}

The majority of the attributes have failed to explain the cross-sectional returns on the JSE over the examination periods (refer to Appendix A.2). DEBTTBVE, amongst other 5 attributes, is the only attribute that exhibits significant payoffs in the examination period. The significant negative payoffs to DEBTTBVE over the second sub-period and the overall examination period reveals that high leveraged firms with substantial financial risk do not impress investors, and are penalized with lower payoffs in the subsequent period.

\section{Fundamental Growth}

Although none of the attributes in the fundamental growth category are significant in explaining the crosssectional equity returns over the first sub-period, 5 out of the 8 attributes in this category (G12MDPS, G12MEPS, G12MNPMARGIN, G24MEPS and GROWTH) exhibit significant payoffs over the second sub-period (refer to Appendix A.3). Although only G12MDPS and G12MEPS pass all four sign tests in the overall period, the payoffs to the attributes (with the exception of GROWTH) in this category are positive over the second sub-period and the entire examination period. This provides some degree of evidence that firms with steady growth in fundamental values are rewarded positively.

\section{Size and Return Momentum}

Appendix A.4 shows that attributes in this category exhibit significant payoffs over both sub-periods with the exception of MOM3. The payoffs to the three size attributes (LAGLPRICE, LPRICE and LSIZE) are significant and consistently negative over the examination periods. This observation is consistent with the well-documented small-firm effect in both local and international research. On the other hand, the mean reversal of MOM1 observed in Van Rensburg and Robertson (2003a) is only found in the first sub-period. The fact that significant positive signs for MOM12, MOM12-1, MOM24 and MOM6 are detected is an indication of their non-exhaustive momentum. Subtracting the most recent 1-month momentum from MOM12, MOM12-1 appears to be the most rewarding shortterm momentum attribute.

\section{Consensus Analyst Forecast}

The data for the attributes in this category is only available from 1999. The characteristics of the payoffs to the attributes displayed in Appendix A.5 show that all four analyst forecasts (EARNREV, EG1, FOREY1 and FOREY2) are rewarded with significant payoffs. This implies that either the analysts have superior abilities in forecasting earnings, or investors, to some degree, follow the recommendations of the analysts.

\section{CONCLUSION}

The examination of the characteristics of the payoffs to the pre-specified attributes show that attributes in the fundamental values relative to share price category, the fundamental growth, the size and momentum category and the consensus analyst forecast category are able to explain the cross-sectional JSE equity returns in their individual capacities. Attributes with significant mean payoffs, in general, are associated with consistent signs for their payoffs. The consistent signs of the attribute payoffs provides indication as to whether the payoffs are fairly priced as theoretically expected, or mispriced. When the signs of the payoffs to the attributes are not in line with their theoretical expectation, the apparent market anomalies are documented and the market corrections/reversals have taken place. Important market anomalies found in this paper include the value effect, the size effect, and the short-term momentum effect. In addition, there seems to be a mild reversal of one-month momentum in the first subperiod. Firms that have relatively high fundamental values relative to their share prices are deemed undervalued and are rewarded positively. Amongst all attributes in the fundamental values relatively to share price category, BVTP and CFTP are the attributes that exhibit the highest and the second highest payoffs over the examination periods.

Another way of assessing the style consistency of the candidate style attributes is to determine whether the magnitudes and the directions of the payoffs are consistent over time. This could be achieved by observing the cumulative attribute payoffs over time. We recommend this area for further research. 


\section{ACKNOWLEDGEMENT}

This work is supported by the National Research Foundation (NRF) of South Africa. We wish to thank the research office of the University of the Western Cape for their support.

\section{AUTHOR INFORMATION}

Dr. Kathleen Hodnett is currently a Research Fellow (funded by the National Research Foundation (NRF) of South Africa) in the School of Business and Finance at the University of the Western Cape, South Africa. She is a member of the International Institute of Forecasters (IIF) and an associate member of the South African Institute of Financial Markets (SAIFM).

Dr. Heng-Hsing Hsieh, CFA is the Head of Finance in the School of Business and Finance at the University of the Western Cape, South Africa. He is a CFA charterholder and a member of the South African Institute of Financial Markets (SAIFM). E-mail: ahsieh@uwc.ac.za. Corresponding Author.

Prof. Paul van Rensburg is the Frank Robb Professor of Finance at the University of Cape Town, South Africa. He is the principal of Salient Quantitative Investment Management. E-mail: paul.vanrensburg@uct.ac.za.

\section{REFERENCES}

1. Achour D, Harvey C R, Hopkins G and C Lang (1999), "Firm Characteristics and Investment Strategies in Africa: The Case of South Africa", African Finance Journal, vol. 1, no 1, 1-67

2. Banz R W (1981), "The Relationship between Return and Market Value of Common Stocks", Journal of Financial Economics, vol. 9, 3-18

3. Basu S (1977), "The Investment Performance of Common Stocks in Relation to Their Price-to-Earnings Ratio: A Test of the Efficient Markets Hypothesis", Journal of Finance, vol. 12, no 1, 129-156

4. $\quad$ Basu S (1983), “The Relationship Between Earnings' Yield, Market Value and The Returns for NYSE Common Stocks: Further Evidence", Journal of Financial Economics, vol. 32, no 3, 663-682

5. Bauman C, Conover C M and R E Miller (1998), "Growth versus Value and Large-Cap versus Small-Cap Stocks in International Markets", Financial Analysts Journal, vol. 54, no 2, 75-89

6. Bhandari L C (1988), "Debt-Equity Ratio and Expected Common Stock Returns", Journal of Finance, vol. 43, no 2, 507-528

7. Blume M and R Stambaugh (1983), "Biases in Computing Returns: An Application to the Size Effect", Journal of Financial Economics, vol. 28, 19-33

8. Bradfield D J, Barr G D and J F Affleck-Graves (1988), "Asset Pricing in Small Markets- The South African Case", South African Journal of Business Management, vol. 19, no 1, 11-21

9 Brennan M T, Chordia and A Subrahmanyam (1998) "Alternative Factor Specification, Security Characteristics and the Cross-Section of Stock Returns", Journal of Financial Economics, vol. 49, 345-373

10. Brown P, Kleidon A W and T A Marsh (1983), "New Evidence on the Nature of Size-Related Anomalies in Stock Prices", Journal of Financial Economics, vol. 12, 33-56

11. Chan K C (1988), "On the Contrarian Investment Strategy”, Journal of Business, vol. 61, no 2, 147-163

12. Chan K C, Hameed A and W Tong (2000), "Profitability of Momentum Strategies in the International Equity Markets", Journal of Financial and Quantitative Analysis, vol. 35, no 2, 153-172

13. Chan L K C and J Lakonishok (2004), "Value and Growth Investing: Review and Update", Financial Analysts Journal, vol. 60, no 1, 71-86

14. Chopra N, Lakonishok J and J R Ritter (1992), "Measuring Abnormal Performance - Do Stocks Overreact?", Journal of Financial Economics, vol. 31, 235-268

15. Claessens S, Dasgupta S and J Glen (1998), "The Cross-Section of Stock Returns: Evidence from the Emerging Markets", Emerging Markets Quarterly, vol. 2, 4-13

16. Daniel K and S Titman (1997), "Evidence on the Characteristics of Cross Sectional Variation in Share Returns", Journal of Finance, vol. 52, no 1, 1-33

17. Daniel K, Titman S and K Wei (2001), "Explaining the Cross-Section of Stock Returns in Japan: Factors or Characteristics", Journal of Finance, vol. 56, 743-766 
18. Davis J L, Fama E F and KR French (2000), “Characteristics, Covariances, and Average Returns: 1929 to 1997”, Journal of Finance, vol. 55, no 1, 389-406

19. De Bondt W F M and R H Thaler (1985), "Does the Stock Market Overreact?”, Journal of Finance, vol. 0, no 3, 793-805

20. De Bondt W F M and R H Thaler (1987), "Further Evidence on Investor Overreaction and Stock Market Seasonality", Journal of Finance, vol. 42, no 3, 557-581

21. De Villiers J, Lowlings A, Pettit A and J Affleck-Graves (1986), “An Investigation into the Small-Firm Effect on the JSE”, South African Journal of Business Management, vol. 17, no 4, 191-195

22. DeFusco R A, McLeavey D W, Pinto J E and D E Runkle (2004), Quantitative Methods for Investment Analysis, $2^{\text {nd }}$ Edition, CFA Institute

23. Fama E F and K R French (1992), "The Cross-Section of Expected Stock Returns", Journal of Finance, vol. 47, 427-465

24. Fama E F and K R French (1993), "Common Risk Factors in the Returns on Stocks and Bonds", Journal of Financial Economics, vol. 33, no 1, 3-56

25. Fama E F and K R French (1996), "Multifactor Explanations of Asset Pricing Anomalies", Journal of Finance, vol. 51, no 4, 55-84

26. Fama E F and K R French (1998), "Value versus Growth: The International Evidence", Journal of Finance, vol. 53, no 6, 1975-1999

27. Fama E F and K R French (2004), "The Capital Asset Pricing Model: Theory and Evidence", Journal of Economic Perspectives, vol. 18, no 3, 25-46

28. Fama E F and K R French (2006), "Profitability, Investment and Average Returns", Journal of Financial Economics, vol. 82, 491-518

29. Fama E F and K R French (2008), "Dissecting Anomalies", Journal of Finance, vol. 63, no 4, $1653-1678$

39. Fama E F and J D Macbeth (1973), "Risk, Return, and Equilibrium”, Journal of Political Economy, vol. 81, no 3, 607-636

31. Ferson W and C Harvey (1999), "Conditioning Variables and the Cross Section of Stock Returns", Journal of Finance, vol. 54, 1325-1360

32. Forner C and J Marhuenda (2003), "Contrarian and Momentum Strategies in the Spanish Stock Market", European Financial Management, vol. 9, 667-88

33. Frankish (2004), Multi-Factor Models and the Cross-Section of Equity Returns, Unpublished Master's Thesis, University of Cape Town

34. Fraser E and M J Page (2000), "Value and Momentum Strategies: Evidence from the JSE", Investment Analysts Journal, vol. 51, 25-35

35. Harvey C (1995), "Predictable Risk and Returns in Emerging Markets", Review of Financial Studies, vol. 8, no 3, 79-88

36. Hodnett K and H Hsieh (2009), "Tests of the Overreaction Hypothesis on the Johannesburg Stock Exchange (JSE) in the Post Millennium ERA", South African Finance Association (SAFA) Conference

37. Jegadeesh N and S Titman (1993), "Returns to Buying Winners and Selling Losers: Implications for Stock Market Efficiency", Journal of Finance, vol. 48, no 1, 65-91

38. Jegadeesh N and S Titman (2001), "Profitability of Momentum Strategies: An Evaluation of Alternative Explanations", Journal of Finance, vol. 56, no 2, 699-720

39. Keim D B (1983), "Size-Related Anomalies and Stock Return Seasonality: Further Empirical Evidence", Journal of Financial Economics, vol. 12, 13-32

40. La Porta R (1996), "Expectations and the Cross-Section of Returns”, Journal of Finance, vol. 51, 17151742

41. La Porta R, Lakonishok J, Shleifer A and R W Vishny (1997), "Good News for Value Stocks", Journal of Finance, vol. 52, no 2, 859-874

42. Lakonishok J, Shleifer A and R W Vishny (1994), “Contrarian Investment, Extrapolation and Risk”, Journal of Finance, vol. 49, no 5, 1541-1578

43. Lintner J (1965), "The Valuation of Risky Assets and the Selection of Risky Investments in Stock Portfolios and Capital Budgets ”, Review of Economics and Statistics, vol. 47, no 1, 13-37

44. Litzenberger R and K Ramaswamy (1979), "The Effects of Personal Taxes and Dividends on Capital AssetPrices: Theory and Empirical Evidence”, Journal of Financial Economics, vol. 7, 163-195 
45. Lo A and A C MacKinlay (1990), "Data-Snooping Biases in Tests of Financial Asset Pricing Models", Review of Financial Studies, vol. 3, no 3, 431-468

46. Lo A and A C MacKinlay (1990), "When are Contrarian Profits Due to Stock Market Overreaction?", Review of Financial Studies, vol. 3, no 2, 175-205

47. Moore (2008), An Investigation of Firm Specific and Macroeconomic Variables and their Influence on Emerging Market stock Returns, Unpublished Master's Thesis, University of Cape Town

48. Mossin J (1966), "Equilibrium in a Capital Asset Market", Econometrica, vol. 34, no 4, 768-783

49. Muller C (1999), "Investor Overreaction on the Johannesburg Stock Exchange", Investment Analysts Journal, no 49, 5-17

50. Page M J (1996), "Further Evidence of Firm Size and Earnings Anomalies on the Johannesburg Stock Exchange", De Ratione, vol. 10, no 1, 27-44

51. Page M J and F Palmer (1993), "The Relationship between Excess Returns, Firm Size and Earnings on the Johannesburg Stock Exchange”, South African Journal of Business Management, vol. 22, no 3, 63-73

52. Reinganum M R (1981), "Misspecification of Capital Asset Pricing - Empirical Anomalies Based on Earnings' Yields and Market Values", Journal of Financial Economics, vol. 9, 19-46

53. Reinganum M R (1983), "The Anomalous Stock Market Behavior of Small Firms in January - Empirical Tests for Tax-Loss Selling Effects", Journal of Financial Economics, vol. 12, 89-104

54. Rosenberg B, Reid K and R Lanstein (1985), "Persuasive Evidence of Market Inefficiency", Journal of Portfolio Management, vol. 11, 9-1

55. Rouwenhorst K G (1999), "Local Return Factors and Turnover in Emerging Stock Markets", Journal of Finance, no 54, 1439-1464

56. Serra A P (2003), “The Cross-Sectional Determinants of Returns: Evidence from Emerging Markets' Stocks, Journal of Emerging Market Finance, vol. 2, no 2, 123-162

57 Sharpe W F (1964), "Capital Asset Prices: A Theory of Market Equilibrium under Conditions of Risk", Journal of Finance, vol. 19, no 3, 425-442

58. $\quad$ Sharpe W F (1966), "Mutual Fund Performance", Journal of Business, vol. 39, no 1, 119-138.

59. Van Rensburg P (2001), “A Decomposition of Style-Based Risk on the JSE”, Investment Analysts Journal, vol. 54, 45-60

60. Van Rensburg P and M Robertson (2003a), "Style Characteristics and the Cross-Section of JSE Returns", Investment Analysts Journal, no 57, 1-10

61. Van Rensburg P and M Robertson (2003b), “Size, Price-to-Earnings and Beta on the JSE”, Investment Analysts Journal, vol. 58, 1-11

62. Van Rensburg and M Robertson (2004), "Explaining the Cross-Section of Returns in South Africa: Attributes of Factor Loadings: Journal of Asset Management, vol 4 No 5, 334-347 


\section{APPENDIX A: Characteristics of Factor Payoffs to Style Attributes}

\section{A.1 Fundamental Values Relative to Share Price}

\begin{tabular}{|c|c|c|c|c|c|}
\hline & BVTP & CFTP & DY & $\mathbf{E Y}$ & SALESTP \\
\hline SUB-PERIOD 1 & & & & & \\
\hline $\begin{array}{l}\text { Factor Payoffs }(97 \mathrm{~m} 01 \text { to } 01 \mathrm{~m} 12) \text { : } \\
\text { Mean Tests: }\end{array}$ & 0.014 & 0.013 & 0.005 & 0.002 & 0.006 \\
\hline$\overline{\text { t-statistic: }}$ & 3.669 & 3.935 & 1.847 & 0.771 & 2.298 \\
\hline Rank: & 2 & 1 & 13 & 24 & 8 \\
\hline \multicolumn{6}{|l|}{ SUB-PERIOD 2} \\
\hline $\begin{array}{l}\text { Factor Payoffs }(02 \mathrm{~m} 01 \text { to } 07 \mathrm{~m} 12) \text { : } \\
\text { Mean Tests: }\end{array}$ & 0.010 & 0.005 & 0.002 & 0.005 & 0.003 \\
\hline t-statistic: & 4.007 & 3.015 & 1.314 & 3.408 & 3.051 \\
\hline Rank: & 6 & 13 & 26 & 9 & 11 \\
\hline \multicolumn{6}{|l|}{ WHOLE PERIOD } \\
\hline $\begin{array}{l}\text { Factor Payoffs }(97 \mathrm{~m} 01 \text { to } 07 \mathrm{~m} 12) \text { : } \\
\text { Mean Tests: }\end{array}$ & 0.012 & 0.009 & 0.004 & 0.003 & 0.004 \\
\hline t-statistic: & 5.284 & 4.803 & 2.248 & 2.267 & 3.286 \\
\hline $\begin{array}{l}\text { Rank: } \\
\text { Median Tests: }\end{array}$ & 2 & 4 & 19 & 18 & 10 \\
\hline Sign (exact binomial): & 90.000 & 85.000 & 79.000 & 76.000 & 83.000 \\
\hline Sign (normal approximation): & 4.187 & 3.831 & 2.762 & 2.227 & 3.474 \\
\hline Wilcoxon signed rank: & 5.059 & 4.672 & 2.693 & 3.036 & 3.801 \\
\hline Van der Waerden (normal scores): & 5.110 & 4.705 & 2.463 & 2.735 & 3.613 \\
\hline No. of Observations > 0 : & 90 & 88 & 82 & 79 & 86 \\
\hline No. of Observations < 0 : & 42 & 44 & 50 & 53 & 46 \\
\hline
\end{tabular}

\section{A.2 Solvency and Liquidity}

\begin{tabular}{|c|c|c|c|c|c|c|}
\hline SUB-PERIOD 1 & CFTCURRLIABS & CFTDEBT & CURRENTRATIO & DEBTTBVE & DEBTTMVE & ICBT \\
\hline $\begin{array}{l}\text { Factor Payoffs }(97 \mathrm{~m} 01 \text { to } 01 \mathrm{~m} 12) \text { : } \\
\text { Mean Tests: }\end{array}$ & 0.000 & -0.001 & 0.002 & -0.002 & 0.003 & -0.001 \\
\hline$\overline{\text { t-statistic: }}$ & 0.029 & -0.342 & 0.572 & -0.857 & 1.127 & -0.330 \\
\hline Rank: & 38 & 33 & 28 & 22 & 19 & 34 \\
\hline \multicolumn{7}{|l|}{ SUB-PERIOD 2} \\
\hline $\begin{array}{l}\text { Factor Payoffs }(02 \mathrm{~m} 01 \text { to } 07 \mathrm{~m} 12) \text { : } \\
\text { Mean Tests: }\end{array}$ & -0.002 & 0.001 & 0.001 & -0.004 & -0.001 & 0.001 \\
\hline t-statistic: & -0.983 & 0.588 & 0.803 & -3.777 & -1.126 & 0.937 \\
\hline Rank: & 29 & 34 & 32 & 7 & 28 & 30 \\
\hline \multicolumn{7}{|l|}{ WHOLE PERIOD } \\
\hline $\begin{array}{l}\text { Factor Payoffs (97m01 to } 07 \mathrm{~m} 12) \text { : } \\
\text { Mean Tests: }\end{array}$ & -0.001 & 0.000 & 0.002 & -0.003 & 0.001 & 0.000 \\
\hline t-statistic: & -0.476 & -0.112 & 0.830 & -2.681 & 0.393 & 0.130 \\
\hline Rank: & 30 & 36 & 26 & 14 & 31 & 35 \\
\hline Median Tests: & & & & & & \\
\hline Sign (exact binomial): & 69.000 & 68.000 & 69.000 & 81.000 & 67.000 & 69.000 \\
\hline Sign (normal approximation): & 0.445 & 0.267 & 0.445 & 2.584 & 0.089 & 0.445 \\
\hline Wilcoxon signed rank: & 0.657 & 1.023 & 0.270 & 3.063 & 0.071 & 0.438 \\
\hline Van der Waerden (normal scores): & 0.249 & 0.736 & 0.400 & -3.027 & 0.297 & 0.402 \\
\hline No. of Observations > 0 : & 69 & 68 & 69 & 51 & 65 & 69 \\
\hline No. of Observations < 0 : & 63 & 64 & 63 & 81 & 67 & 63 \\
\hline
\end{tabular}




\section{A.3 Fundamental Growth}

\begin{tabular}{|c|c|c|c|c|c|c|c|c|}
\hline SUB-PERIOD 1 & G12MCPS & G12MDPS & G12MEPS & G12MGPMARGIN & G12MNPMARGIN & G12MSALES & G24MEPS & GROWTH \\
\hline $\begin{array}{l}\text { Factor Payoffs }(97 \mathrm{~m} 01 \text { to } \\
\text { 01m12): } \\
\text { Mean Tests: }\end{array}$ & 0.002 & 0.004 & 0.003 & 0.001 & 0.003 & 0.002 & -0.001 & -0.002 \\
\hline t-statistic: & 0.767 & 1.709 & 1.136 & 0.399 & 1.269 & 0.676 & -0.194 & -0.802 \\
\hline Rank: & 25 & 14 & 18 & 31 & 15 & 26 & 36 & 23 \\
\hline SUB-PERIOD 2 & & & & & & & & \\
\hline $\begin{array}{l}\text { Factor Payoffs }(02 \mathrm{~m} 01 \text { to } \\
\text { 07m12): } \\
\text { Mean Tests: }\end{array}$ & 0.002 & 0.004 & 0.005 & 0.000 & 0.004 & 0.002 & 0.004 & 0.002 \\
\hline t-statistic: & 1.256 & 3.033 & 3.146 & 0.314 & 2.688 & 1.547 & 2.811 & 2.025 \\
\hline Rank: & 27 & 12 & 10 & 35 & 17 & 23 & 16 & 20 \\
\hline WHOLE PERIOD & & & & & & & & \\
\hline $\begin{array}{l}\text { Factor Payoffs }(97 \mathrm{~m} 01 \text { to } \\
\text { 07m12): } \\
\text { Mean Tests: }\end{array}$ & 0.002 & 0.004 & 0.004 & 0.001 & 0.003 & 0.002 & 0.002 & 0.000 \\
\hline t-statistic: & 1.325 & 3.005 & 2.645 & 0.508 & 2.543 & 1.332 & 1.133 & 0.195 \\
\hline $\begin{array}{l}\text { Rank: } \\
\text { Median Tests: }\end{array}$ & 23 & 12 & 15 & 29 & 16 & 22 & 25 & 33 \\
\hline Sign (exact binomial): & 71.000 & 81.000 & 77.000 & 65.000 & 74.000 & 68.000 & 79.000 & 71.000 \\
\hline Sign (normal approximation): & 0.802 & 2.584 & 2.405 & 0.267 & 1.336 & 0.267 & 2.227 & 0.802 \\
\hline $\begin{array}{l}\text { Wilcoxon signed rank: } \\
\text { van der Waerden (normal }\end{array}$ & 1.083 & 3.099 & 2.866 & 0.253 & 2.089 & 0.903 & 1.984 & 0.747 \\
\hline scores): & 1.206 & 2.941 & 2.630 & 0.342 & 2.334 & 1.172 & 1.521 & 0.491 \\
\hline No. of Observations > 0 : & 71 & 81 & 80 & 64 & 74 & 68 & 79 & 71 \\
\hline No. of Observations < 0 : & 61 & 51 & 52 & 68 & 58 & 64 & 53 & 61 \\
\hline
\end{tabular}

\section{A.4 Size and Return Momentum}

\begin{tabular}{|c|c|c|c|c|c|c|c|c|c|}
\hline SUB-PERIOD 1 & LAGLPRICE & LPRICE & LSIZE & MOM1 & MOM12 & MOM12-1 & MOM24 & MOM3 & MOM6 \\
\hline $\begin{array}{l}\text { Factor Payoffs }(97 \mathrm{~m} 01 \text { to } 01 \mathrm{~m} 12) \text { : } \\
\text { Mean Tests: }\end{array}$ & -0.008 & -0.009 & -0.006 & -0.007 & 0.007 & 0.009 & 0.006 & 0.002 & 0.005 \\
\hline t-statistic: & -2.800 & -3.009 & -2.019 & -2.061 & 2.454 & 3.242 & 1.866 & 0.661 & 1.236 \\
\hline Rank: & 6 & 5 & 11 & 10 & 7 & 3 & 12 & 27 & 16 \\
\hline SUB-PERIOD 2 & & & & & & & & & \\
\hline $\begin{array}{l}\text { Factor Payoffs }(02 \mathrm{~m} 01 \text { to } 07 \mathrm{~m} 12) \text { : } \\
\text { Mean Tests: }\end{array}$ & -0.009 & -0.009 & -0.010 & -0.001 & 0.006 & 0.007 & 0.006 & 0.001 & 0.006 \\
\hline t-statistic: & -5.098 & -5.075 & -5.131 & -0.295 & 2.824 & 3.417 & 2.891 & 0.302 & 2.569 \\
\hline Rank: & 2 & 3 & 1 & 37 & 15 & 8 & 14 & 36 & 18 \\
\hline WHOLE PERIOD & & & & & & & & & \\
\hline $\begin{array}{l}\text { Factor Payoffs }(97 \mathrm{~m} 01 \text { to } 07 \mathrm{~m} 12) \text { : } \\
\text { Mean Tests: }\end{array}$ & -0.008 & -0.009 & -0.008 & -0.004 & 0.007 & 0.008 & 0.006 & 0.001 & 0.005 \\
\hline t-statistic: & -5.227 & -5.365 & -4.626 & -1.809 & 3.702 & 4.681 & 3.206 & 0.720 & 2.442 \\
\hline $\begin{array}{l}\text { Rank: } \\
\text { Median Tests: }\end{array}$ & 3 & 1 & 6 & 21 & 7 & 5 & 11 & 27 & 17 \\
\hline Sign (exact binomial): & 87.000 & 90.000 & 90.000 & 78.000 & 86.000 & 91.000 & 84.000 & 69.000 & 74.000 \\
\hline Sign (normal approximation): & 3.653 & 4.187 & 4.187 & 2.049 & 3.474 & 4.365 & 3.118 & 0.445 & 1.336 \\
\hline Wilcoxon signed rank: & 4.787 & 4.894 & 4.414 & 1.607 & 3.747 & 4.607 & 3.389 & 1.220 & 2.496 \\
\hline van der Waerden (normal scores): & -4.760 & -4.821 & -4.267 & -1.645 & 3.630 & 4.468 & 3.232 & 1.160 & 2.484 \\
\hline No. of Observations > 0 : & 45 & 42 & 42 & 54 & 86 & 91 & 84 & 69 & 74 \\
\hline No. of Observations < 0 : & 87 & 90 & 90 & 78 & 46 & 41 & 48 & 63 & 58 \\
\hline
\end{tabular}


A.5 Consensus Analyst Forecast

\begin{tabular}{|c|c|c|c|c|}
\hline & EARNREV & EG1 & FOREY1 & FOREY2 \\
\hline \multicolumn{5}{|l|}{ SUB-PERIOD 1} \\
\hline $\begin{array}{l}\text { Factor Payoffs }(97 \mathrm{~m} 01 \text { to } 01 \mathrm{~m} 12) \text { : } \\
\text { Mean Tests: }\end{array}$ & 0.008 & 0.001 & 0.005 & 0.008 \\
\hline t-statistic: & 2.239 & 0.148 & 1.217 & 3.113 \\
\hline Rank: & 9 & 37 & 17 & 4 \\
\hline \multicolumn{5}{|l|}{ SUB-PERIOD 2} \\
\hline $\begin{array}{l}\text { Factor Payoffs }(02 \mathrm{~m} 01 \text { to } 07 \mathrm{~m} 12) \text { : } \\
\text { Mean Tests: }\end{array}$ & 0.003 & 0.005 & 0.006 & 0.002 \\
\hline t-statistic: & 1.958 & 4.191 & 4.913 & 2.211 \\
\hline Rank: & 22 & 5 & 4 & 19 \\
\hline \multicolumn{5}{|l|}{ WHOLE PERIOD } \\
\hline $\begin{array}{l}\text { Factor Payoffs }(97 \mathrm{~m} 01 \text { to } 07 \mathrm{~m} 12) \text { : } \\
\text { Mean Tests: }\end{array}$ & 0.005 & 0.003 & 0.006 & 0.004 \\
\hline t-statistic: & 2.968 & 1.993 & 3.487 & 3.690 \\
\hline $\begin{array}{l}\text { Rank: } \\
\text { Median Tests: }\end{array}$ & 13 & 20 & 9 & 8 \\
\hline Sign (exact binomial): & 57.000 & 57.000 & 64.000 & 64.000 \\
\hline Sign (normal approximation): & 0.985 & 0.883 & 2.255 & 2.255 \\
\hline Wilcoxon signed rank: & 2.045 & 1.769 & 3.420 & 3.325 \\
\hline van der Waerden (normal scores): & 2.523 & 1.870 & 3.491 & 3.481 \\
\hline No. of Observations >0: & 57 & 57 & 64 & 64 \\
\hline No. of Observations < 0 : & 46 & 47 & 40 & 40 \\
\hline
\end{tabular}




\section{NOTES}

